\title{
Application of the SHALSTAB model for the identification of areas susceptible to landslides: Brazilian case studies.
}

\author{
Tiago Damas MARTINS ${ }^{1}$ Bianca Carvalho VIEIRA ${ }^{2}$, Nelson Ferreira FERNANDES ${ }^{3}$, Chisato OKA- \\ FIORI ${ }^{4}$, David, R. MONTGOMERY ${ }^{5}$ \\ ${ }^{1}$ Cities Institute, Federal University of São Paulo, São Paulo, Brazil \\ 2 Department of Geography, University of São Paulo, São Paulo, Brazil. \\ ${ }^{3}$ Department of Geography, Federal University of Rio de Janeiro, Rio de Janeiro, Brazil \\ 4 Department of Geography, Federal University of Paraná, Paraná, Brazil \\ ${ }^{5}$ Department of Earth and Space Sciences, University of Washington, USA
}

Received 5 November 2017; Revised 20 November 2017; Accepted 1 December 2017

*Correspondence to: Bianca Carvalho VIEIRA, e-mail: biancacv@usp.br

\begin{abstract}
Since the 1960s, catastrophic and generalized events of hazardous mass movements caused millions of dollars in economic losses and resulted in thousands of fatalities and homelessness in Brazil. To understand these processes and attempt to predict them, mathematical models have been utilized world-wide describing the physics of the process through mathematical equations. The objective of this study was to present two areas widely affected by shallow landslides where the SHALSTAB model was applied to understand the process and to predict potentially unstable areas in several hydrographic basins. Simulations utilized the types of distinct data that were available in each area. From both areas, geotechnical data collected in the field, topographical data from digital topographical maps and Digital Terrain Models (DTM) from Light Detection and Ranging (LiDAR) were utilized. Susceptibility maps were validated using two indexes, scar concentration (SC) and landslide potential (LP), based on landslides that occurred in 1985 and 2011. Both indexes showed satisfactory results given that the unconditionally unstable category described more than $45 \%$ of the landslide events, and the LP index displayed the highest values for the most unstable categories.
\end{abstract}

\section{KEYWORDS}

Serra do Mar; LiDAR; Landslide Potential; Natural Disasters 


\section{Introduction}

Landslides in Brazil occur predominantly in steep slopes associated with high rainfall indexes, particularly in summer. Between 1988 and 2015, 4,000 fatalities were recorded as a consequence of 773 events in 243 municipalities (Macedo and Martins, 2015). These authors also showed that the states of Rio de Janeiro, Sao Paulo, Minas Gerais and Santa Catarina had the highest number of fatalities. Starting in the 1960s, important events considered catastrophic were recorded, resulting in millions of dollars in economic losses, thousands of fatalities and homelessness. A few events marked the history of Brazil, particularly in the years 1966, 1967, 1985, 1988, 1995, 2008, 2009, 2010, 2011 and 2014 (Fig. 1).

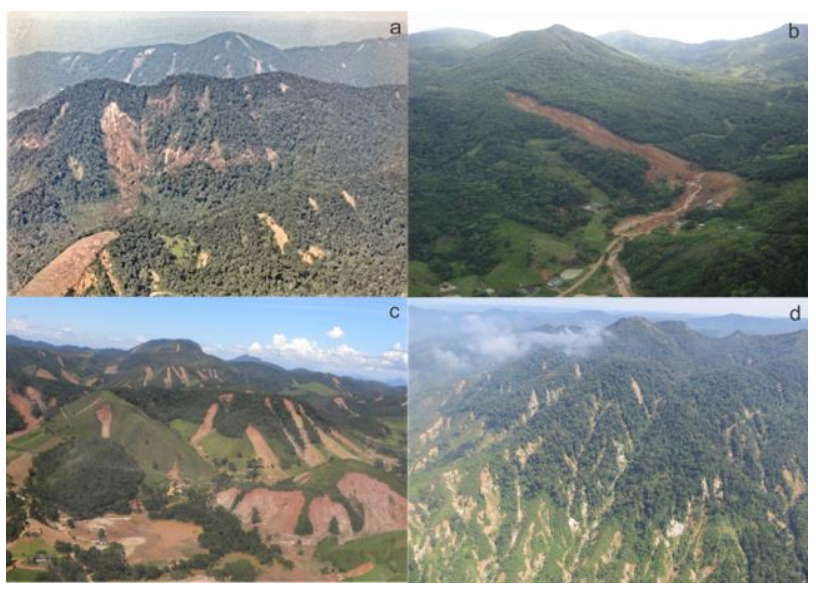

Figure 1 (a) Mass movements at Serra do Mar near the municipality of Caraguatatuba in 1966/1967, at Santa Catarina in 2008, at Rio de Janeiro in 2011 and at São Paulo in 2014. Sources (a) Caraguatatuba municipality archives, (b) and (d) photo credits: Marcelo Gramani, and (c) personal archives

\section{Serra do Mar and Study Areas: Copebrás Basin and Bom Brinquedo Basin}

The Serra do Mar mountain range in southern Brazil is a geological-geomorphological compartment that extends for $1,500 \mathrm{~km}$. It is characterized by frequent mass movements associated with the rainy season between December and March when $60 \%$ of the annual mean precipitation of $3,300 \mathrm{~mm}$ occurs
(Meis and Silva, 1968; Fúlfaro et al., 1976; de Ploey and Cruz, 1979).

One of the largest events occurred in the municipality of Caraguatatuba, São Paulo State, where precipitation reached $947 \mathrm{~mm}$ in March 1967, with $115 \mathrm{~mm}$ on the $17^{\text {th }}$ and $420 \mathrm{~mm}$ on the $18^{\text {th }}$ of that month. This triggered numerous landslides and debris flows across a radius of $15 \mathrm{~km}$ resulting in 440 fatalities (de Ploey and Cruz, 1979).

On January $23^{\text {rd }}$ and $24^{\text {th }}, 1985,380 \mathrm{~mm}$ of rain over a $48 \mathrm{~h}$ period, corresponding to 40 to $60 \%$ of the typical January monthly rainfall in the area, caused severe shallow landslides that reached the main drainage network at Serra do Mar in the municipality of Cubatão (state of São Paulo), and caused a highly destructive debris flow (Massad et al., 2000; Kanji et al., 2003).

On January $11^{\text {th }}$ and $12^{\text {th }}, 2011$, rainfall reached approximately $300 \mathrm{~mm} / 48 \mathrm{~h}$ and more than eight municipalities in the Serra do Mar region located in Rio de Janeiro were affected by 3,562 landslides that caused more than 1,500 deaths and serious damage to urban and rural infrastructures due to heavy preceding rainfall (Coelho Netto et al., 2011).

In view of this, efforts have been made to comprehend mechanisms that trigger these processes and to integrate factors related to the soil, topography, morphometry of relief and drainage, rainfall volume, and hydrological monitoring (Fernandes et al., 2004). Furthermore, particularly after the 2011 mass movement events, the Brazilian government passed a law related to the production of susceptibility maps, particularly regarding landslides and flooding, to ensure the production of maps that indicate areas with higher or lower degree of susceptibility focused on hydrographic basins.

To exemplify the application of the SHALSTAB model, two areas in Serra do Mar that were widely affected by shallow landslides in different periods were selected, one located in the state of São Paulo and one in the state of Paraná (Figures 2 and 3).

Serra do Mar is one of the most relevant orographic features in the Atlantic coast of the South American continent, and it is known for 
having the most "Tormented" relief in Brazil due to its slopes, tectonic processes and faults. It is an outstanding feature in the Brazilian terrain for its grand geomorphological features and its role on human occupation from the colonial period to present (Almeida, 1953).

Geomorphological features in the São Paulo State portion of Serra do Mar display several natural features, primarily those associated with lithological, structural and climatic conditions. Geologically, the main escarpments of this unity are associated with the most resistant rocks such as granite, granite gneiss, alkaline and basic intrusions and quartzite. Thus, natural processes of mass movement are common in this area, which is subjected to high annual mean rainfall and long-lasting rainfall events. Some stretches display the highest volumes of rain in Brazil, together with the Amazon region, where approximately $5,000 \mathrm{~mm} /$ year has been recorded.

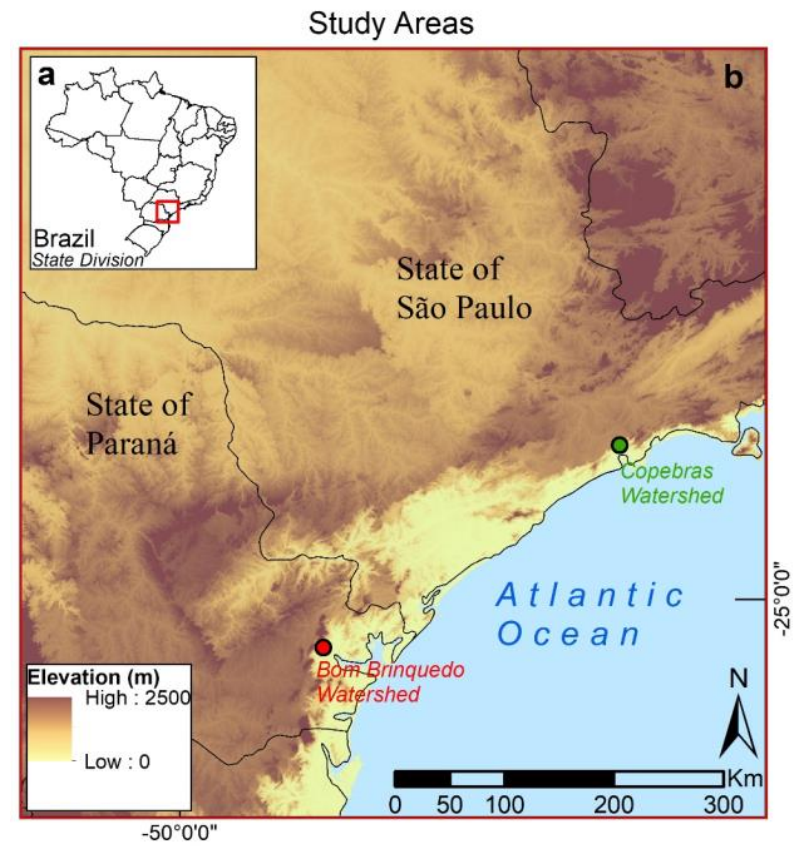

Figure 2 Location of the two basins in the states of São Paulo and Paraná related to Serra do Mar.

The Copebrás Basin in São Paulo state extends for $3.6 \mathrm{~km}^{2}$ and was affected by approximately 400 shallow landslides on January $23^{\text {rd }}$ and $24^{\text {th }}, 1985$. The basin is located in a heavy-traffic highway network through which a large portion of Brazilian exports are transported to the port of Santos. The Cubatão Industrial Park is also located in this region, where the main petrochemical companies in the country are hosted. Migmatite and schists are the predominant rock types, $60 \%$ of the escarpments are convex and concave at 30 to 40 degree angles, and a large portion faces the southeast, south and southwest (Vieira et al., 2010).

The Bom Brinquedo Basin extends for $0.16 \mathrm{~km}^{2}$ and is located north of the urban perimeter of the Antonina municipality (state of Paraná). In March 2011, the municipality was affected by generalized mass movements triggered by $98.6 \mathrm{~mm}$ of rainfall on the day of the occurrence and an accumulation of $263 \mathrm{~mm}$ between March $1^{\text {st }}$ and March 11 ${ }^{\text {th }}, 2011$. In this basin area, porphyritic granite is the predominant rock type, interspaced by diabase dikes, with the slopes most affected by landslides having an inclination of $20^{\circ}$ to $30^{\circ}$ and predominantly concave (Martins et al., 2017b).

\section{Methods and Materials}

\subsection{Model}

One of the methods used to predict shallow landslides in susceptible areas employs physicsbased mathematical models, which physically describe the processes through mathematical equations and disregard the subjective or direct opinion of the researcher. Beginning in the 1990s, two important physics-based mathematical models were developed: the Distributed, Physically Based Slope Stability Model (dSLAM), created by Wu and Sidle (1995), and the Shallow Landsliding Stability Model (SHALSTAB) of Montgomery and Dietrich (1994). In the late 1990s and early 2000s, three additional models were developed: Stability INdex MAPping (SINMAP) by Pack et al. (1998); Pack et al. (2001); Transient Rainfall Infiltration And Grid-Based Regional Slope Stability (TRIGRS) and Shallow Landslides Instability Prediction (SLIP) by Montrasio and Valentino (2008).

SHALSTAB was developed from propositions by Montgomery and Dietrich (1994), Montgomery et al. (1998) and Dietrich et al. (1998) that spatially represent the potential susceptibility of shallow translational landslide occurrences for a given hydrographic basin with the compilation of a slope 
stability model and a steady-state hydrological model, which is analyzed based on the topography. The combined models provide a ratio between the precipitation and soil transmissivity that can lead to slope failure (Equation 1). The first model is based on the slope stability model that uses the infinite slope equation, which defines a ratio between the support tension and material destabilization. The second model is based on the propositions by O'Loughlin (1986), who considers the ratio between the concentration and transmissivity of water in the soil, providing the spatial standard of soil saturation equilibrium, defined by an upstream source area. The combined model may be expressed in terms of the critical ratio of rainfall to soil transmissivity necessary to cause a landslide:

$\log \left(\frac{\mathrm{q}}{\mathrm{T}}\right)=\frac{\operatorname{sen} \theta}{\left(\frac{\mathrm{a}}{\mathrm{b}}\right)}\left[\frac{\mathrm{C}^{\prime}}{\rho_{\mathrm{w}} \mathrm{gzcos} \cos ^{2} \theta \tan \phi}+\frac{\rho_{\mathrm{s}}}{\rho_{\mathrm{w}}}\left(1-\frac{\tan \theta}{\tan \phi}\right)\right]$

where,

$\mathrm{q}=$ critical rainfall to cause rupture $[\mathrm{mm} /$ day $]$

$\mathrm{T}=$ soil transmissivity $\left[\mathrm{m}^{2} /\right.$ day $]$

$\mathrm{a}=$ contribution area $\left[\mathrm{m}^{2}\right]$

$\mathrm{b}=$ length of cell contour $[\mathrm{m}]$

$\theta=$ slope angle $\left[{ }^{\circ}\right]$

$\rho \mathrm{w}=$ water density $\left[\mathrm{g} / \mathrm{cm}^{3}\right]$

$\mathrm{g}=$ gravity acceleration $[\mathrm{m} / \mathrm{s}]$

$\mathrm{z}=$ soil thickness $[\mathrm{m}]$

$\rho s=$ global density of saturated soil $\left[\mathrm{g} / \mathrm{cm}^{3}\right]$

$\phi=$ angle of internal friction $\left[^{\circ}\right]$

$c^{\prime}=$ effective soil cohesion $[\mathrm{kPa}]$

In Brazil, most studies utilize mainly the SHALSTAB (Guimarães et al., 2003; Fernandes et al., 2004; Zaidan and Fernandes, 2009; Vieira and Ramos, 2015; Martins et al., 2016) and SINMAP models (Lopes, 2006; Michel et al., 2014; Nery and Vieira, 2014) and, to a lesser extent, the TRIGRS model (Rabaco, 2005; Vieira et al., 2010). Thus, the objective of this study was to present two areas widely affected by shallow landslides in Serra do Mar where the SHALSTAB model was applied to understand the process and to predict unstable areas in hydrographic basins of distinct dimensions.

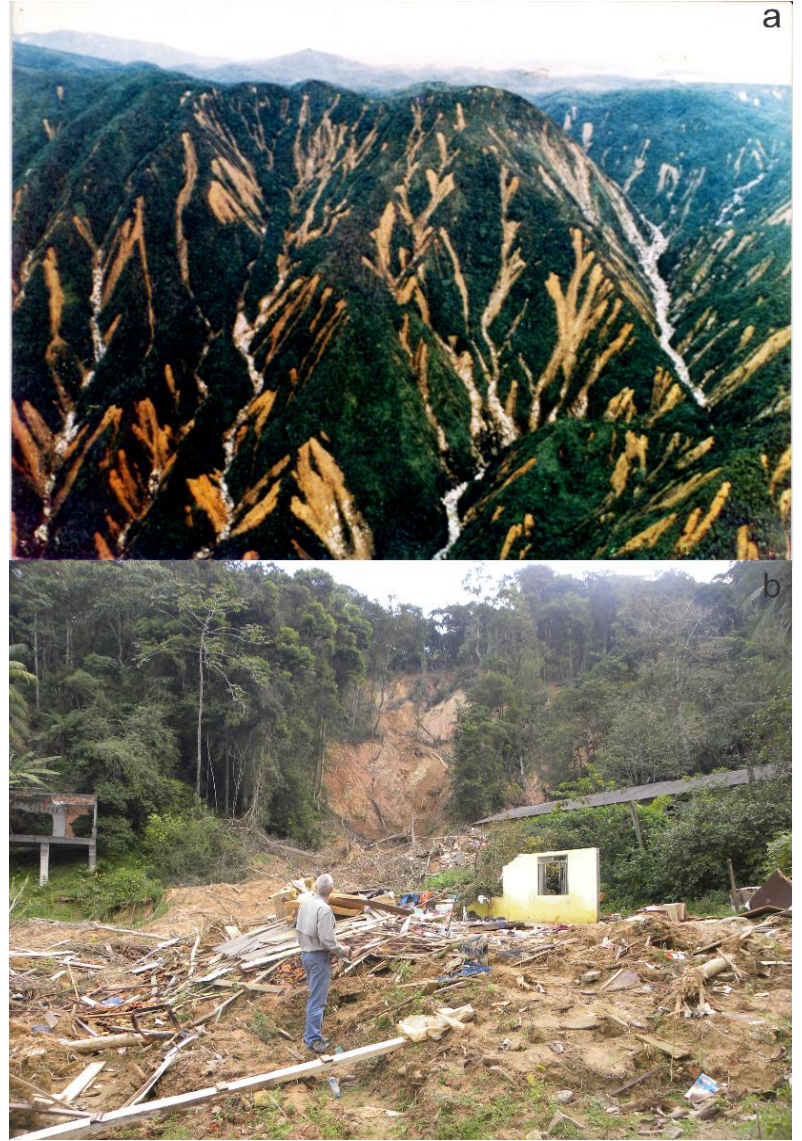

Figure 3 (a) Generalized landslides in Serra do Mar near the Copebrás Basin. Source: Institute for Technological Research of São Paulo and (b) landslide in the Bom Brinquedo Basin. Source: personal archives.

\subsection{Topographic Data}

To evaluate the landslide susceptibility, simulated scenarios were created using data available from each area. For the Copebrás Basin, a $5 \mathrm{~m}$ resolution Digital Terrain Model (DTM) was used from a topographic contour map at a 1:10,000 scale.

For the Bom Brinquedo Basin, the $1 \mathrm{~m}$ resolution DTM was obtained from an airborne LiDAR system using an OPTECH 2050 device. Raw data from LiDAR were processed in ArcGis Desktop version 10.3 (http://desktop.arcgis.com/en/arcmap/ 10.3/get-started/quick-start-guides/arcgis-desktopquick-start-guide.htm). First the LiDAR data was filtered to include only data corresponding to the terrain using the LAS Dataset toolbox, subsequently it was applied the Natural Neighbor interpolator to 
generate a raster surface. While these settings were appropriate to generate the DTM, limitations were identified caused by the data point density corresponding to terrain and, consequently, the interpolation of these points in a continuous surface. These limitations tend to directly affect the grid quality and, thus, the spatial resolution of the cells. These limitations are discussed in the literature for quite some time, e.g., Cowen et al. (2000), who evaluated the effects of forest canopy density on the number of points corresponding to terrain, estimating that between $10 \%$ and $40 \%$ of the laser pulses will reach the terrain surface in an area of $80 \%$ and $90 \%$ of forest coverage.

\subsection{Geotechnical Data}

To generate susceptibility scenarios for both basins, field data collected in other studies were used. For the Copebrás Basin, geotechnical data by WOLLE and CARVALHO (1989) were used, who collected and analyzed field data near one of the scars (Table 1). This was one of the main in situ geotechnical and hydrological surveys that aimed to understand infiltration of pluvial waters in non-saturated soils and its effect on triggering shallow translational landslides by the elimination of suction pressure. In this study, two pilot areas in Serra do Mar located on steep $\left(>30^{\circ}\right)$, linear slopes were selected, one of which is near the Copebrás Basin.

Table 1 Topographic and geotechnical data used in both

\begin{tabular}{lcc}
\multicolumn{3}{c}{ basins. } \\
\hline $\begin{array}{c}\text { Parameters [unit]; } \\
\text { Basin }\end{array}$ & Copebrás & $\begin{array}{c}\text { Bom } \\
\text { Brinquedo }\end{array}$ \\
\hline DTM & $\begin{array}{c}\text { topographic map } \\
(1: 10.000 \text { scale })\end{array}$ & LiDAR \\
\hline Soil cohesion (c) [Pa] & 1000 & 0 \\
\hline $\begin{array}{l}\text { Internal angle of } \\
\text { friction }(\Phi)\left[{ }^{\circ}\right]\end{array}$ & 34 & 31 \\
\hline $\begin{array}{l}\text { Total unit weight of } \\
\text { soil }\left(\boldsymbol{p}_{\mathbf{s}}\right)\left[\mathbf{g} / \mathbf{c m}^{\mathbf{3}} \text { ] }\right.\end{array}$ & 1.7 & 2.6 \\
\hline $\begin{array}{l}\text { Soil maximum } \\
\text { thickness } \mathbf{( z )}[\mathbf{m}]\end{array}$ & 3.0 & 1.0 \\
\hline
\end{tabular}

For the Bom Brinquedo Basin, detailed in situ geotechnical data were obtained by Lopes (2013) for soil physical properties (angle of friction, cohesion, natural relative specific weight and saturated relative specific weight) to correlate soil thickness and the water table level within unstable areas of the slopes.

\subsection{Validation of the Susceptibility Maps}

To validate the susceptibility maps, two indexes were used based on scar maps of landslides that occurred in 1985 in the Copebrás Basin and in 2011 in the Bom Brinquedo Basin: scar concentration (SC), defined as the ratio between the number of cells from each category affected by scars and the total cells affected in the basin; and landslide potential $(L P)$, defined as the ratio between the number of cells from each category affected by scars and the total number of cells from the corresponding category.

The Copebrás Basin scar map was generated from an aero-photogrammetric survey (color diapositive infrared films) performed by the National Institute of Spatial Research in August 1985 at a 1:25,000 scale. Mapping was based on a visual analysis using the absence of vegetation and the slope position as the primary criteria. Slope position was defined from other studies performed in the Serra do Mar in São Paulo State, showing that ruptures of shallow translational landslides occur in the upper third portion of the scar.

The scar map for the Bom Brinquedo Basin was obtained by Martins et al. (2017a) by evaluating previous studies and producing a new map based on the terrain morphology characteristics, such as slope inclination and curvature associated with the contribution of the basin area.

\section{Results and Discussion}

\subsection{Copebrás Basin}

Class frequency ( $F$ ) showed that $30 \%$ to $40 \%$ of the basin area was classified as unconditionally unstable (Figures 4 and 5). The area corresponding to the other categories decreased dramatically, remaining fairly constant until the class $\log (\mathrm{Q} / \mathrm{T})>-2.2$. The unconditionally stable category occupied less than $7 \%$. 


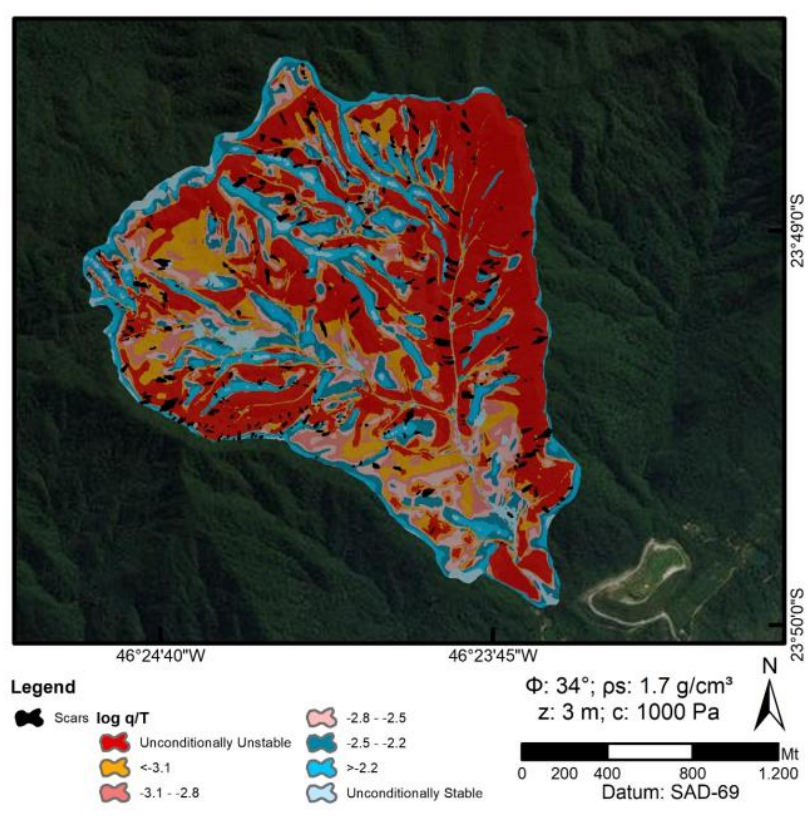

Figure 4 Copebrás Basin susceptibility map.

The evaluation of SC showed that the unconditionally unstable category characterized approximately $66 \%$ of the scars. However, considering the cumulative percentages of this index in each class, $76 \%$ of the landslides were in the $\log (\mathrm{Q} / \mathrm{T})<-3.1$ category, $82 \%$ in the $\log (\mathrm{Q} / \mathrm{T})<-$ 2.8 category, and $89 \%$ in the $\log (\mathrm{Q} / \mathrm{T})<-2.5$ category. These results are similar to those reported by Montgomery and Dietrich (1994) and Dietrich et al. (1998) in studies in the Western United States, for which $83 \%$ to $100 \%$ of the scars were characterized by $\log (\mathrm{Q} / \mathrm{T})<-2.5$. Slightly lower cumulative percentages were obtained by Dietrich et al. (1998), who identified that only $54 \%$ of the landslides correspond to $\log (\mathrm{Q} / \mathrm{T})<-3.1,68 \%$ correspond to $\log (\mathrm{Q} / \mathrm{T})<-2.8$ and $90 \%$ correspond to $\log$ $(\mathrm{Q} / \mathrm{T})<-2.5$.

Such variability in scar concentrations, considering the cumulative percentages and the limits of $\log (\mathrm{Q} / \mathrm{T})$, is a function of the quality and resolution of the DTM grids. According to these authors, to obtain more than $60 \%$ of the scars in a $30 \mathrm{~m}^{2}$ grid, a log $(\mathrm{Q} / \mathrm{T})<-2.5$ limit is needed. For a 10 $\mathrm{m}^{2}$ resolution grid, a log $(\mathrm{Q} / \mathrm{T})<-2.8$ limit may be more appropriate and for high resolution DTM, the limit can be log $(\mathrm{Q} / \mathrm{T})<-3.1$.
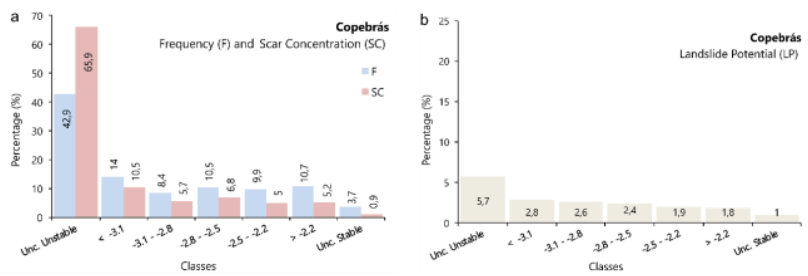

Figure 5 Susceptibility class distribution (F), scar concentration (SC) and landslide potential (LP).

The LP analysis reveals a better agreement between the SHALSTAB predictions and the scar map. The highest LP indexes were recorded in the unconditionally unstable category, decreasing dramatically in the $\log (\mathrm{Q} / \mathrm{T})<-3.1$ category and then gradually until the $\log (\mathrm{Q} / \mathrm{T})>2.2$ category. The lowest LP values were identified in the unconditionally stable category.

\subsection{Bom Brinquedo Basin}

In contrast to the previous basin, the highest frequency values were obtained for the two most stable categories (unconditionally stable and log $\mathrm{Q} / \mathrm{T}<-2.2$ ), which together represented almost $80 \%$, followed by the unconditionally unstable category, which corresponded to approximately 20\% (Figures 6 and 7).

The four intermediate classes had very low values that altogether accounted for less than $1 \%$, and two categories had null values ( $\log \mathrm{q} / \mathrm{T}-2.8$ to 2.5 and -2.5 to -2.2 ). However, in the SC index, the unconditionally unstable category had the highest value, nearly $45 \%$ of the scars, and the two most stable categories together accounted for $55 \%$ of the scars.

Notably, scars occurred in all areas defined as unconditionally unstable, which is considered a positive model output. Although there are areas belonging to this category that were not involved in the 2011 event, they can still be considered susceptible to slope failure given that the model does not provide a timeframe for the occurrence of landslides. Thus, it is not feasible to interpret an overestimation of the model in that regard.

Intermediate categories also displayed null values or values lower than $0.12 \%$ for this index, which was reflected in the LP and, in turn, had the 
highest values for the unconditionally unstable $(24.80 \%)$ and the $\log q / T<-3.1(20 \%)$ categories. The two most stable classes displayed values similar to the previous scenarios, together accounting for nearly $16 \%$ of the basin area. The classes log $q / T$ $<-3.1$ and -3.1 to -2.8 had high values for this index despite being less relevant when the frequency and scar concentration results were analyzed.

The distribution of values and particularly the null values in some of the categories are similar to results previously reported by (Martins et al., 2017a), including null values for the same categories. These authors analyzed the effects of data in the generation of the Digital Terrain Model, comparing models generated from contours and from LiDAR, using the SHALSTAB in a basin adjacent to the Bom Brinquedo Basin.

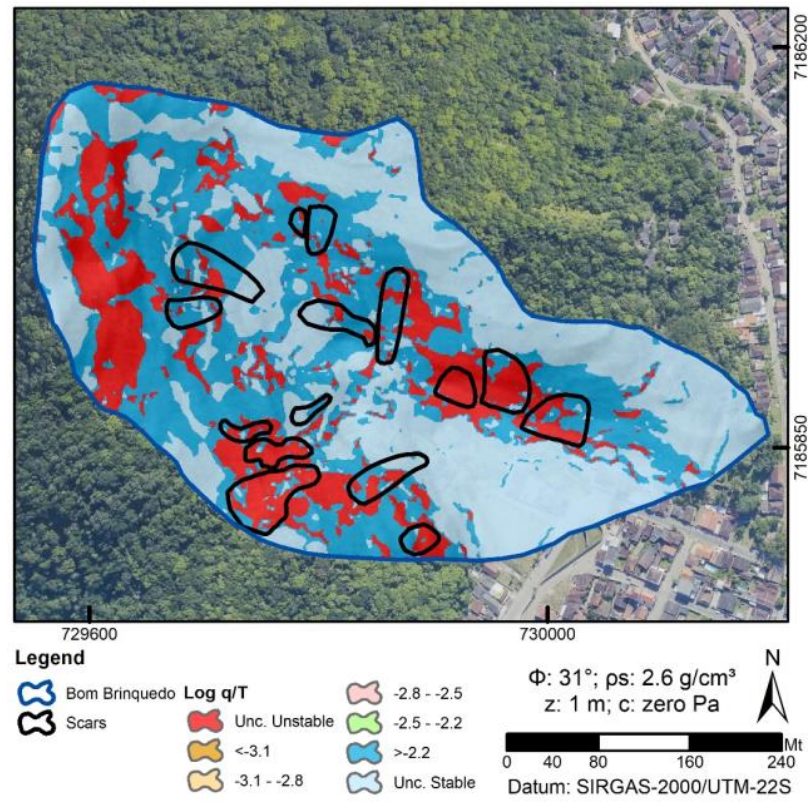

Figure 6 Bom Brinquedo Basin susceptibility map.

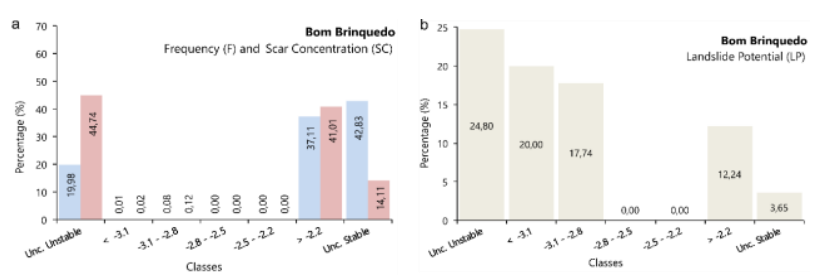

Figure 7 Susceptibility category distribution (F), scar concentration (SC) and landslide potential (LP).
In the context of Serra do Mar, it is important to highlight that some authors argue that landslides can occur when permeable materials are in direct contact with less permeable materials in the altered mantle, which favors the rapid development of positive pore pressure. Another rupture mechanism is associated with the loss of suction and decreased apparent cohesion due to the continuous increase of deep hydraulic conductivity. Such an increase may be due to the presence of fracture systems in the altered mantle, which allow the drainage of subsuperficial water and prevent total soil saturation (WOLLE and CARVALHO, 1989; Kanji et al., 2003; Gerscovich et al., 2006; Lacerda, 2007). Our results showing that these areas are unconditionally unstable mean that they should fail when dry - this means that root strength (which is not considered in the model as formulated here) is critically important for stabilizing slopes.

\section{Conclusions}

The effect of these processes in developing countries is associated in most cases with human loss in highly occupied urban areas, which can be attributed to the absence of preventive measures and the intense landscape alterations. Therefore, the SHALSTAB model can be combined with land use maps can contribute on assessment of vulnerability and risk. However, even with the great potential for public management, SHALSTAB, as well as other mathematical predictive models, are rarely used for this purpose in Brazil. The LP analysis revealed the agreement between the SHALSTAB predictions and the scar map, especially because the highest LP indexes were recorded in the unconditionally unstable category, decreasing until the log $(\mathrm{Q} / \mathrm{T})>2.8$ category. The model performance tested in Brazil comparably to performance in Western North America, indicate it as viable tool for identifying potentially hazardous zones in the tropical region.

\section{Acknowledgements}

The authors thank the São Paulo Research Foundation (FAPESP 2014/10109-2), the Coordination for the Improvement of Higher 
Education Personnel (CAPES BEX 5188/14-8) and FACEPE (BFP-0072-1.07/16) for partial financial support for this research.

\section{References}

Almeida FFM. 1953. Considerações sobre a geomorfogênese da Serra de Cubatão. Boletim Paulista de Geografia 15:3-17.

Coelho Netto AL, Sato AM, Avelar AS, Vianna LGG, Araujo IS, Croix D, Lima P, Silva AP, Pereira R. 2011. January 2011: the extreme landslide disater in Brazil. In: Proc. 2nd World Lansdlides Forum. Rome.

Cowen DJ, Jensen JR, Hendrix C, Hodgson ME, Schili SR. 2000. A GIS-Assisted Rail Construction Econometric Model that Incorporates LIDAR Data Photogrammetric Engineering \& Remote Sensing 66:1323-1328.

de Ploey J, Cruz O. 1979. Landslides in the Serra do Mar, Brazil. CATENA 6:111-122.

Dietrich WE, Asua RRD, Orr JB, Trso M. 1998. A validation study of the shallow slope stability model, SHALSTAB, in the forest lands of Northern California. In. Stillwater Ecosystem, Watershaded \& Riverine Sciences, Berkeley.

Fernandes NF, Guimarães RF, Gomes RAT, Vieira BC, Montgomery DR, Greenberg H. 2004. Topographic controls of landslides in Rio de Janeiro: field evidence and modeling. CATENA 55:163-181.

Fúlfaro VJ, Ponçano WL, Bistrichi CA, Stein DP. 1976. Escorregamentos de Caraguatatuba: expressão atual, e registro na coluna sedimentar da planície costeira adjacente. In: CBGE, Rio de Janeiro. p 341-350.

Gerscovich DMS, Vargas EA, de Campos TMP. 2006. On the evaluation of unsaturated flow in a natural slope in Rio de Janeiro, Brazil. Engineering Geology 88:23-40.

Guimarães RF, Montgomery DR, Greenberg HM, Fernandes NF, Trancoso Gomes RA, de Carvalho OAl. 2003. Parameterization of soil properties for a model of topographic controls on shallow landsliding: application to Rio de Janeiro. Engineering Geology 69:99-108.

Kanji MA, Massad D, F., Cruz PT. 2003. Debris Flows in Areas of Residual Soils: Occurrence and Characteristics. In: Associacione Geotecnica Italiana, editor. International Workshop on Occurrence and Mechanism of Flows in Natural Slopes and Earthfills. Napoles p1-9.

Lacerda WA. 2007. Landslide initiation in saprolite and colluvium in southern Brazil: Field and laboratory observations. Geomorphology 87:104-119.
Lopes ESS. 2006. Modelagem Espacial Dinâmica em Sistema de Informação Geográfica: Uma Aplicação ao Estudo de Movimentos de Massa em Uma Região da Serra do Mar Paulista. In: Universidade Estadual Paulista. p 314.

Lopes FCA. 2013. Avaliação da Influência da Distribuição Espacial da Espessura do Solo e do Nível Freático na Estabilidade de Encosta. In: Universidade Federal do Paraná,. p 126.

Macedo ESd, Martins PPD. 2015. Análise do Banco de Dados de Mortes por Deslizamentos do Instituto de Pesquisas Tecnológicas (IPT). In: $15^{\circ}$ Congresso Brasileiro de Geologia de Engenharia e Ambiental

Martins T, Oka-Fiori C, Vieira B, Montgomery D. 2016. Assessment of Lidar-derived DTMs for landslide susceptibility mapping: Application in the Brazilian subtropical forest.1389-1392.

Martins TD, Oka-Fiori C, Vieira BC, Bateira CVM, Montgomery DR. 2017a. AvaliaÇÃo De Mdt Na Modelagem De Instabilidade De Vertentes. Raega - $O$ Espaço Geográfico em Análise 41:07.

Martins TD, Oka-Fiori C, Vieira BC, Correa ACdB, Bateira CVM. 2017b. AnÁlise Dos ParÂmetros MorfolÓgicos E Os Escorregamentos Rasos Na Serra Do Mar, ParanÁ. Caminhos de Geografia 18:223-239.

Massad F, Cruz PT, Kanji MAE, Araujo Filho HA. 2000. Characteristics and Volume of Sediment Transported in Debris Flows in Serra do Mar, Cubatão, Brasil. In: International Workshop on Debris Flow Disaster of December 1999 in Venezuela. Caracas, Venezuela.

Meis MRM, Silva JX. 1968. Considerações Geomorfológicas a Propósito dos Movimentos de Massa Ocorridos no Rio de Janeiro. In: Revista Brasileira de Geografia. p 32-50.

Michel GP, Kobiyama M, Goerl RF. 2014. Comparative analysis of SHALSTAB and SINMAP for landslide susceptibility mapping in the Cunha River basin, southern Brazil. Journal of Soils and Sediments 14:1266-1277.

Montgomery DR, Dietrich WE. 1994. A physically based model for the topographic control on shallow landsliding. Water Resources Research 30:1153-1171.

Montgomery DR, Sullivan K, Greenberg HM. 1998. Regional test of a model for shallow landsliding. Hydrological Processes 12:943-955.

Montrasio L, Valentino R. 2008. A model for triggering mechanisms of shallow landslides. Natural Hazards and Earth System Science 8:1149-1159.

Nery TD, Vieira BC. 2014. Susceptibility to shallow landslides in a drainage basin in the Serra do Mar, São Paulo, Brazil, predicted using the SINMAP mathematical model. Bulletin of Engineering Geology and the Environment 74:369-378. 
O'Loughlin EM. 1986. Prediction of Surface Saturation Zones in Natural Catchments by Topographic Analysis. In: Water Resources Research. p 794-804.

Pack RT, Tarboton DG, Goodwin CN. 1998. Terrain Stability mapping with SINMAP, Technical description and users guide for version 1.00. In. $\mathrm{p} 68$.

Pack RT, Tarboton DG, Goodwin CN. 2001. Assessing Terrain Stability in a GIS using SINMAP. In: 15th annual GIS conference, GIS. Vancouver, British Columbia. p 19-22.

Rabaco LML. 2005. Avaliação de Modelos de Susceptibilidade a Movimentos Gravitacionais de Massa numa Faixa de Dutos. In. Rio de Janeiro: Universidade do Estado do Rio de Janeiro. p 162.

Vieira BC, Fernandes NF, Filho OA. 2010. Shallow landslide prediction in the Serra do Mar, São Paulo, Brazil. Natural Hazards and Earth System Science 10:1829-1837.
Vieira BC, Ramos H. 2015. Aplicação do modelo Shalstab para mapeamento da suscetilidade a escorregamentos rasos em Caraguatatuba, Serra do Mar (SP). Geography Department University of Sao Paulo 29:161.

WOLLE CM, CARVALHO CS. 1989. Deslizamentos em encostas na Serra do Mar - Brasil. Solos e Rochas.27-36.

Wu W, Sidle RC. 1995. A Distributed Slope Stability Model for Steep Forested Basins. Water Resources Research 31:2097-2110.

Zaidan RT, Fernandes NF. 2009. Zoneamento de Suscetibilidade a Escorregamentos Rasos em Encostas Aplicado à Bacia de Drenagem Urbana do Córrego do Independência - Juiz de Fora (MG). Revista Brasileira de Geomorfologia 10:57-76. 